\title{
ROE and Value Creation under IAS/IFRS: Evidence of Discordance from French Firms
}

\author{
Mohamed El Hedi AROURI* - Aldo LÉVY ${ }^{* *}$ \\ Duc Khuong NGUYEN ${ }^{* * *}$
}

\section{Introduction}

In Europe, the International Accounting Standards and International Financial Reporting Standards (IAS/IFRS) came into force on January 1, 2005 under EC Regulation No. 1606/2002 of the European Parliament and its Council. ${ }^{1}$ Firms listed on stock exchanges within the European Union were required to publish their 2004 financial statements in IFRS format in order to provide greater uniformity in the presentation of accounting information across all countries, owing to the growing integration of the financial markets, and thereby to make it easier for investors to interpret the financial performance. The application of the new accounting system became mandatory as of January 1, 2007 for firms making public offerings other than by issuing shares. Generally speaking, the adoption of the IFRS is a clear indication of a policy of convergence, considered by most economic actors to be an inevitable development in

Prof. Mohamed El Hedi Arouri - Associate Professor of Finance, University of Orleans \& EDHEC Business School, Rue de Blois - BP 6739, 45067 Orléans cedex 2, France; <mohamed.arouri@univ-orleans.fr>.

** Prof. Aldo Lévy - Professor of Management Accounting, GREG-CRC, CNAM, 292 Rue Saint-Martin, 75003 Paris, France; <aldo.levy@cnam.fr>.

**** Prof. Duc Khuong Nguyen - Associate Professor of Finance, ISC Paris School of Management, 22 Boulevard du Fort de Vaux, 75017 Paris, France; $<$ dnguyen@groupeisc.com>.

1 It is important to note that some of the IAS standards drafted by the IASC (International Accounting Standards Committee) still remained in use after the adoption of the IFRS. However, for reasons of brevity, in this article we will use IFRS only when referring to the new accounting system. 
the area of financial accounting and reporting as practiced by the IASB and the FASB. ${ }^{2}$

Because of the scope of the changes required by moving to the IFRS, numerous studies have examined their impacts on the economic and financial performance of listed companies, the compliance of financial reporting with IFRS, the quality of the accounting information published in IFRS format, and the process of convergence between the international and national standards (Bertoni and De Rosa, 2006; Callao et al., 2007; Bischof, 2009). A number of studies have also addressed the impacts of the new accounting system on the actions of local and international regulators (Shipper, 2005; Whittington, 2005), and tested the effects of the voluntary adoption of IFRS standards (Cuijpers and Buijink, 2005; Dumontier and Magrahoui, 2006). Taken together, these studies have shown that the adoption of IFRS significantly affects the performance measures for listed firms, particularly financial ones. Moreover, they identified a considerable number of problems in implementing the IFRS in Europe owing to their differences with respect to Anglo-Saxon countries, especially in terms of business characteristics and the legal, cultural, and institutional aspects of accounting regulations (Joos and Lang, 1994; Ding et al., 2007). The lack of uniformity of these same factors within the European Union also impedes the process of convergence between Member States.

It is also accepted that restatement according to IFRS standards was intended to bring the firm's book value as close as possible to its market value, through a number of mechanisms. In fact, by favouring the economic approach (substance over form) to the detriment of the historical and fiscal approach generally applied in Europe before 2005, the new system is expected to provide more relevant financial information, enabling investors to make informed investment decisions and, specifically, to allocate their funds to the most productive uses (Street et al., 2000). The expected improvement in the transparency and quality of information would then reduce agency costs, the risks of accounting income being manipulated, and the cost of capital (Botosan and Plumlee, 2002; Leuz, 2003). However, during the global financial crisis of 2007-2008 these standards still failed to deliver the anticipated

2 These acronyms denote the International Accounting Standards Board and Financial Accounting Standards Board, which respectively drafted the IFRS and US GAAP. The US GAAP represents the accounting system for Anglo-Saxon countries. 
transparency and quality of information, and even showed evidence of procyclicality (Laux and Leuz, 2010). Among the problems encountered, questions were raised concerning the use of fair value (IAS 32, IAS 39, and IFRS 7) as the basis for the valuation of most financial instruments, formerly recorded as off-balance-sheet items, because it was no longer possible to apply the principle correctly with the markets at a standstill. The IASB had to react quickly, and on October 13, 2008 it adopted an amendment to IAS 39 designed to allow the reclassification of certain financial instruments, which had previously been strictly prohibited by the standard.

This article contributes to previous studies by examining the connections between the information content of accounting numbers under IFRS and financial performance as perceived by the financial markets in the context of France. We devote particular attention to the construction and interpretation of Return on Equity (ROE), a key indicator in the value creation for shareholders. Note that in France listed companies were the first to publish their consolidated financial statements under both French GAAP and IFRS in 2005, followed by firms that make public offerings; lastly, the IFRS rules for SMEs are now being formulated, naturally with some lightening of the requirements, but there is nevertheless a strong convergence. An examination of the French case is of interest for several reasons. Firstly, French companies, unlike those in Germany, Austria, and Switzerland, were not allowed a transition period for adapting to the international standards before they were introduced in January 2005. This was mainly due to the 1998 revision of the IAS 1 standard, which mandated compliance with all of the IAS standards. Next, among a number of differences between the IFRS and French standards (orientation towards financial information for investors versus accounting law for companies and businesses; exclusive consideration of consolidated accounts versus distinction between corporate and consolidated accounts, etc.), we note a profound divergence between these two systems in the use of the fair-value principle to the detriment of historical costs in the valuation of assets and liabilities. Accordingly, the impact of the new system on French companies could be stronger than in other European countries. Finally, although an important body of the existing literature has investigated the economic consequences of IFRS adoption, little is known about their impact on key financial ratios. For instance, Lantto and Sahlström (2009) find significant changes in key accounting figures and financial ratios including the return on equity after the conversion of Finnish GAAP to 
IFRS. Note that our study differs from the latter in the sense that we will not only show the changes in return on equity for French listed firms, but also how this privileged indicator for financial community is becoming difficult to be interpreted with respect to value creation purpose and unreliable in terms of financial performance measure under the IFRS.

We show that the objective sought by the IASB - greater transparency of accounting information - has not been achieved, in that financial performance as calculated under the IFRS has become axiomatic (i.e., having more symbols than content). In fact, our empirical study of the consolidated financial statements of CAC 40 firms highlights the extent of the financial reframing problems, and that the simple analysis of financial performance based on financial statements has not gained in clarity. In examining the errant procedures of IAS 39 and the opportunistic management of fair value, we find a lack of agreement concerning Return on Equity and the way in which it creates value. For this reason, Merton (1987) valuation model, which was supposed to converge with the CAPM (Capital Asset Pricing Model) owing to the underlying downward trend in the cost of information, is moving away from it because of divergences in the reassessment of the firms' worth, while the root cause of the crisis has still not been eradicated.

The rest of this article is organised as follows. Section 2 discusses both the interaction between accounting standards and financial information, and the opportunistic management of performance following the introduction of the IFRS. Sections 3 and 4 analyse the impacts of the new accounting system on financial profitability and show the abuses of this indicator by using data from companies belonging to the CAC 40 index. The last section provides some concluding remarks.

\section{Financial information and accounting standards}

\subsection{Financial reporting and agents' positions}

Financial reporting on companies is intended for everyone: both insiders and simple investors. Corporate financial information is essential for the investor and especially for financial analysts (Beaver, 1968; Brown and Han, 1992). Note in this regard that the informational influence of financial analysts is growing, because as soon as information is published they instantaneously correct the financial markets by 
providing both endogenous and exogenous information. Lang and Lundholm (1996) found that financial analysts are in principle favourable to firms renowned for the quality of their financial information, and their executives thus have a strategic interest in disclosing as much information as possible to financial analysts, at an early date. A number of studies have found a positive correlation between the voluntary publication of information by firms and the forecasting activities of analysts (Lang and Lundholm, 1996; Bozzolan et al., 2009). The growing role of information in the relationship between the firm and its stakeholders means that we are moving towards the direct marketing of corporate stocks, which is modelled on the marketing of services even although it still remains a financial matter.

On the other hand, several empirical studies demonstrated that stock prices and trading volume are influenced by analysts and their recommendations (Peterson and Peterson, 1995). More recent works have correlated the increase in a firm's value and the quality of financial reporting on the cost of debt (Sengupta, 1998), the cost of capital (Diamond and Verrecchia, 1994; Botosan, 1997), and the improvement in liquidity (Kim and Verrecchia, 1994). The versatility of non-institutional investors, due to the information they obtain, adds a new cost, since the cost of debt is inversely proportional to how long securities are held.

Regarding the interaction between financial reporting and agents' positions, agency and signalling theories attempt to explain the opportunistic decision to publish financial information or rumours by agency costs and information asymmetry. For Jensen and Meckling (1976), agency costs appear to be important for listed firms whose capital is diluted, and for those who are considerably levered. Agency costs can actually be reduced through the production and dissemination of information by the firms. Similarly, executives may have a special interest in signalling to the financial market an increase in the value of the firm or a decrease in the cost of capital (Frankel et al., 1995; Sengupta, 1998). Finally, to explain the ability of financial information to reduce the asymmetry of information, signalling theory relies on the models of Milgrom (1981) and Grossman (1981), for whom voluntary publication by firms homogenises investor expectations (Atiase and Bamber, 1994).

In France, listed companies began in 2005 to publish their financial statements according to both the French GAAP and IFRS. This disclosure of information was intended to improve the quality of information about 
the companies (Schipper, 2005) and to make them easier to compare in terms of their performance. However, it has allowed a localisation of the divergence in accounting principles, and it seems that with the adoption of international accounting standards, financial reporting can now be understood only by certain experts, and reflects an opportunistic strategy on the part of the agents rather than a desire for increased transparency, perhaps following the example of financial products created by securitisation. Lev and Zarowin (1999) emphasised the loss of relevance of accounting data by demonstrating a significant and continuous deterioration of the link between reported accounting figures and stock prices. This situation would become worse under the IFRS because they require that the informative content provided voluntarily by firms be relevant for the market. This is all the more important since the linear relationship between stock prices and the accounting information released seems to be well confirmed (Ohlson, 1995).

The study by Tort (2005) indicates that for eight property companies listed on the NYSE Euronext-Paris that reported their financial statements under both the French GAAP and IFRS, the move from one set to the other causes the net income to surge. The income has more than doubled, on average, mainly owing to the application of fair value valuation to buildings and to the adjustment of consolidated goodwill. In terms of standard deviation, among firms that opted for fair value two had an increase of from $30 \%$ to $66 \%$ in their incomes. Using a different approach, Ramond et al. (2007) show the dominance of net income over fair-value income (comprehensive income) in explaining stock returns of a sample of companies listed both in France and the UK.

There is thus good reason to temper the infatuation with fair value (IAS 16, IAS 37-41), which is supposed to provide a better basis for financial information, the goal of fair value being however to reduce the discrepancy between a firm's market capitalisation and its book value of equity. The superimposition of multiple sets of standards (IAS/IFRS, French GAAP or "Plan Comptable Général" 2005, US GAAP, etc.) certainly makes the interpretation of financial information a tricky business, and brings it into disrepute.

\subsection{Opportunistic management of performance}

The need to harmonise accounting standards and practices so as to "facilitate the understanding of financial statements, provide confidence- 
worthy information, and contribute to the stability of markets, economies, and corporate financing" is one of the conclusions of the Bouton report submitted to the French employer organisation - MEDEF (Bouton, 2002). We are thus essentially counting on the competence of the administrators, but their financial competence is not defined either by the Commercial Code or by reports on corporate governance.

The distortions between the book and market values of companies have led to an increasing discrepancy between them. The book-to-market ratio, measured by the book value divided by the market value, continues to weaken. This discrepancy is mainly explained by the incorrect valuation of securities by investors. It is evident that with the transition to the IAS/IFRS rules we are seeing an inability of financial statements to faithfully reproduce the financial reality of the firm. This leads to the socalled opportunistic management of accounting income when financial performance does not achieve the predicted income objectives (Jiraporn et al., 2008).

In France, several accounting options under the national standards can be applied to the accruals calculated from the income statement in order to produce adjustment variables so much that they even give prominence to a strong relationship between stock returns and opportunistic management of these flows. Thus, the opportunistic earnings management mainly addresses this portion, which is left to the discretion of the manager (discretionary accruals). Although these accounting opportunities under the French GAAP have hitherto allowed an adjustment of the net income according to management's expectations, the temptation to adjust the value of items under IAS/IFRS as opportunities arise seems greater. This is exacerbated by the fact that if an activity sector actually offers high average profits, a manager whose company is performing poorly may present accounting incomes that are boosted by the self-valuation permitted under fair value, while the investors have no idea that these incomes are the product of opportunistic management (Park and Rio, 2004).

It has even been shown that in the event of a substantial increase in indebtedness, management is inclined to practice an opportunistic management of income. For example, Richardson and Tuna (2002) found that indebtedness represents a determinant for the opportunistic earnings management. The most levered firms would make adjustments even when income was increasing, to present a more secure financial situation and 
obtain external financing at lower cost. The securitisation technique is therefore a means of presenting a more solid balance sheet and promoting over-indebtedness, enabling financial firms to get around the prudential ratios.

Starting from the principle that an increase in debt makes agency problems worse, creditors and States impose restrictive clauses expressed in the form of mandatory ratios to ensure protection. Managers then began to select opportunistic accounting methods and to automatically reduce the chances of violating these clauses. Finally, the concept of theoretical return on equity in "traditional" financial analysis has become axiomatic with worldwide adoption of the IAS/IFRS system.

\section{Theoretical return on equity}

Although they are crucial documents in assessing the financial adequacy of a firm, financial statements are coming under increasing scrutiny. The financial (or accounting) ratios derived from these financial statements, and in particular the profitability, formerly constituted reliable indicators for the investor. But, the IFRS would seem to be causing its components to drift. This section firstly describes the calculation of the return on equity commonly used in the French standards, and secondly comments on the changes in this ratio caused by the introduction of the IFRS.

\subsection{Construction of the ROE}

Of the various profitability and return measures, the return on equity (ROE) is of particular interest to managers and owners as it reflects the firm's overall financial efficiency and performance. It is generally expressed as the ratio of net income to shareholders' equity. A number of authors have sought to adjust the model's numerator and denominator, and have given good reasons for doing do. However, an unverifiable bias may lead to doubts concerning the calculation of this financial return, and the IAS/IFRS are the source of subjective interpretations of the value of the accounting items involved.

The ROE has recently become very popular, since the famous $15 \%$ threshold absolutely had to be crossed. The major problem posed by the ROE concerns the interpretation of its components. The numerator (net 
income) depends simultaneously on the accounting policy, the financial performance, and any extraordinary profits and losses, which makes it easy for companies to manipulate under the IAS/IFRS system. Moreover, a reduction in shareholders' equity (e.g., possibility of recording components as financial debt or as expenses) leads to better ROE without any improvement in performance. In fact, the ROE expressed as a combination of firm's economic return (return on capital employed) and financial leverage effects can no longer be taken for granted.

With the coming of the IFRS, accounting data and information have undergone significant deviations in their measurement, owing to a certain laxity in their accounting encouraged by said standards. These standards were globalised precisely in order to perform comparisons between entities, but have had the opposite result. We indeed see that return on equity has now become hard to check as between one firm and another, or even to monitor for the same firm over several periods.

Traditionally, one of the key elements of ROE was the optimal value of debt and its leverage effect. The relative stability of the cost of debt explains the reducing effect and the principle according to which it would be in the firm's interest to maximise its debt so as to improve its financial performance. Although the benefits and limits of the model are well known, they will now be less controllable under the IAS/IFRS system. It is sometimes stated that changes in the balance sheet items caused by the IAS/IFRS cancel each other out because reciprocal amounts are recorded in the asset and liability sides. However, the ratios formulating the ROE in terms of the economic return and the debt structure do not offset each other.

By analysing the incomes of shareholders in comparable indebted and debt-free companies, Modigliani and Miller (1958) established that in presence of market frictions the value of an indebted company exceeds that of a company that does not carry a debt. Simply because shareholders in an unlevered firm (i.e., it is financed by equity uniquely) have operating income net of tax, whereas those in a similar but levered firm (i.e., it is financed by equity and debt) have net operating income and the surplus of tax-deductible interests. Consequently, the firm's value is greater if it is indebted, since the shareholders benefit from the goodwill comparable to a sort of tax income due to the tax shield, which is considered as an off-balance-sheet profitable intangible asset. Thus the significant variable at the heart of the return differential for the 
shareholders is the tax deductibility of the financial expenses, i.e., the cost of the debt.

In addition, it seems that the relationship between the level of indebtedness and the level of noncurrent assets under the IFRS does not always appear to be coherent, because $i$ ) for firms that are growing rapidly (with sizable intangible assets), the cost of default would be higher, and in fact the maximum leverage ratio would be at a lower level than for more mature firms; ii) there would be a strong correlation between on the one hand the return on capital employed and on the other hand the level of indebtedness and the intangible assets.

In practice, the fact that firms have to restate the intangibles under the IAS/IFRS may conceal a risk of default. An inspection of the consolidated financial statements of several firms shows for example that the intangible assets published in 2005 by Casino fell from $€ 3,310$ million to $€ 248$ million, those of TF1 dropped by $86 \%$, going from about $€ 900$ million to $€ 125$ million, and those of Bouygues went from $€ 6,425$ million to $€ 1,025$ million, thus a reduction of $84 \%$.

Under the IAS/IFRS only development costs can be capitalised, whereas the costs of research are expressly excluded from the assets. It is however important to underline that not all intangible assets fall, since those of $\mathrm{LVMH}$ went from $€ 3,923$ million to $€ 4,217$ million after application of the IFRS or an increase of $25 \%$. Other asset items are also affected, e.g., LVMH's noncurrent assets went from $€ 12,559$ million to $€ 25,527$ million under the IFRS or a $102 \%$ increase, and noncurrent debt from $€ 5,340$ million to $€ 10,779$ million or an increase of more than $100 \%$.

Lastly, we note that not only the assets but also income items are affected. For example, Casino's operating income increased by $17 \%$, the first-quarter net income of the LVMH group rose by $18 \%$, and so on.

\subsection{Adjustment of the accounting figures under the IFRS}

The equilibrium model of return on equity has been subject to critics. First, it had been found too rigid, because it assumes that income from financial operations is practically nonexistent, that there are no significant financial charges other than interest expenses, and that extraordinary profits and losses are insignificant. Now, this becomes less restrictive 
with the IAS/IFRS system, where reductions of a financial nature included in the net financial expenses are reallocated to the proceeds of ordinary activities or to provisions, or even worse as a deduction from the cost of assets without going through the expense accounts concerned. Extraordinary profits and losses become, moreover, reduced to their most simple form.

Second, it appears to be too simplified, because the recording of borrowed capital in the balance sheet remains ambiguous. Effectively, if we consider only the noncurrent debt, the calculation of the weighted average cost of debt is certainly consistent, but it implicitly assumes that the other items in the current liabilities have no cost and that the income is not thereby affected in any way. If, on the other hand, we consider all of the liabilities, we then take into consideration debts that are not necessarily financial, but current. The whole is therefore heterogeneous, because it ignores the source of the debt, and especially their cost and maturity. Further, the combination of cheap resources (i.e., the resources required for working capital according to IAS 7 are assumed to be less costly and their systematic use confirms the resurgence of the proprietary approach), settlement delays, and the turnover of invested funds is not without effect on value assessment. The adoption of IFRS has a strong impact here because the data for balance-sheet items (both noncurrent and current) are strongly reallocated.

Third, the equilibrium model of return on equity is equally found to be fiscally inappropriate, because the income taxes are formulated simply. In fact, the equation for pre-tax ROE is crudely multiplied by $(1-\tau)$ to allow for its impact. ${ }^{3}$ However, the calculation of corporate tax is based on the taxable income, not the accounting income. Accordingly, reasoning in the absence of taxation information, as Modigliani and Miller (1958) initially did, appears to be completely irrelevant for the model, but wanting to allow for it by multiplying by $(1-\tau)$ was no more practical. The IAS/IFRS rules then introduce a new approach for deferred taxes which changes the

The equilibrium model of return on equity after tax, assuming the nonexistence of non recurrent items, may be stated as

$$
R O E=R O C E+\left[(R O C E-i) \times \frac{D}{E}\right] \times(1-\tau),
$$

where $R O C E, i, D, E$ and $\tau$ correspond to the return on capital employed, interest rate, financial debts, shareholder equity, and tax rate on the value of corporate profits respectively. 
analysis by bringing the taxable and accounting incomes as closely as possible. For this purpose, we could have considered an operating income which is net of tax, but it would then have been necessary to find the share of tax on operating activities, and that would have added assumptions to the problem. In addition, the IAS/IFRS system largely correct for the gap between the current operating income and the net income by minimising the extraordinary portion to bring, but this correction does not reflect the true effects of corporate income taxes.

Forth, the ROE model is judged too broad because capital is not dated, but lumped together on the balance sheet date. The ratios formulating the ROE are thus calculated on the basis of an average amount of capital invested over the duration of the value-creation process, which is the source and destination of the income. Note that the errors of earnings analysis based on recent flows, but reduced to balance-sheet items that have not been restated, have been taken into account when analysing corporate accounts. To this extent, the Banque de France's financial statement database has long been the perfect example. Its approach has moreover always had the advantage of restating the economic and financial data in a transparent and uniform manner, enabling comparative analysis across firms. This seems to be the right approach for listed firms. But when all firms have systematically applied the IAS/IFRS with all the possibilities these standards offer for revaluing each year to a value considered as fair for them, for the balance-sheet items, and consequently for the items in the income statement, we are witnessing a distortion of incomes and financial return ratios between comparable firms.

Finally, the ROE model under the IFRS appears to be too schematic. Indeed, the discount rate formally used for discounting future cash flows, which also determines the threshold for the leverage effect as well as the profitability threshold and the appropriate risk level, is no longer exogenous to the system for recording accounting data. The reason is that its use was now systematic to calculate the acceptable return on an investment, and under the IFRS rules the discount rate is pegged to the fair-value calculation. Discounting, which was essentially an external recalculation of financial values, is under the IFRS, applied in an internal manner to prepare "opportunistic" financial documents at management's discretion. Whatever the importance of the leverage effect for the ROE, let us assume that a firm has created additional values all the more so its ROE is high. We then bring these two concepts together, which is 
mathematically explicable but may also explain reversals in the market trend, as seen during the crisis of 2007 and subsequently, based on information other than the accounting data.

Practically, the 2004 report by the Institute of Chartered Accountants in England and Wales had also shown the limits of the IAS-IFRS rules:

- Financial and accounting information based on the precautionary principle is defensible even though it makes far too little the intangible assets on which many activities are based. But it is exactly this precautionary principle that has been banished;

- Traditional financial information is focused on figures that reflect the firm's profits. However, this information is not properly placed in perspective with the associated limits and risks under the IFRS. The transparency principle is only minimally respected.

Meanwhile for the French case, the Banque de France's financial statement database had corrected PCG's income statement intermediate balances and non-operating items by using aggregate indicators. It also established a cash-flow statement beginning in the 1990s which reintroduced different cash-flow levels by highlighting the FTEs (Operating Cash Flows), FTIs (Investment Cash Flows), and FTFs (Financing Cash Flows), as in the cash-flow statement required by IAS 7.

Hitherto, any analyst who wishes to restate the indicators could refer to an established standard. However, new financial indicators have now appeared with many items being removed or added, and no consensus has so far been reached. We can note that

- EBITDA (Earnings before Interest, Taxes, Depreciation and Amortisation) seems to be imposing itself at the international level. But, EBITDA has no standardised definition and the IFRS standards have not taken a position on the matter;

- The Operating Income, measured by the difference between EBITDA and the sum of depreciation and amortisation, resembles the income from operating activities, but how they might be distinguished is not stated.

- The Operating Profit refers to all the proceeds and expenses from continuing and discontinued operations that are independent from financial activity and income tax, but the disappearance of the extraordinary profits and losses will inflate it or bring it down. 
As long as it was only a matter of tools for financial analysts the penalty for their inappropriate use was a poor assessment, a bad prediction, and a market penalty. But with the IAS/IFRS it is internalised, becoming part of the accounting where value judgments are made.

\section{Axiomatic return on equity}

\subsection{Synoptic table of occurrences}

Financial equalisation is not affected in the same way by the various IFRS standards, and their main effects are summarised in Table 1. The analysis is based on the way in which the ROE is calculated, as follows:

$$
R O E=\left(\frac{E B I T[2]}{N R[1]}\right) \cdot\left(\frac{N R[1]}{N A[6]+N W C[7]}\right) \cdot\left(\frac{N I[3]}{E B I T[2]}\right) \cdot\left(\frac{D[5]+S E[4]}{S E[4]}\right)
$$

\begin{tabular}{|c|c|c|c|}
\hline$\frac{\text { (Operating }}{\text { margin) }}$. & $\begin{array}{l}\text { (Turnover of } \\
\text { invested funds) }\end{array}$ & $\begin{array}{c}\text { (Cost of } \\
\text { debt })\end{array}$ & $\begin{array}{l}\text { (Financial } \\
\text { leverage) }\end{array}$ \\
\hline Return on & pital employed & Deb & ructure \\
\hline
\end{tabular}

In practice, Equation (1) can be also expressed differently by replacing the sum $N A[6]+N W C[7]$ by Total Assets, and the sum $D[5]+S E[4]$ by Total Liabilities including shareholder equity. The second component of the ROE is then referred to as asset turnover ratio, assessing how assets are efficiently used within the business entity. 
Arrouri, M. E. H. - Lévy, A. - Nguyen, D. K.: ROE and Value Creation under

IAS/IFRS: Evidence of Discordance from French Firms.

Tab. 1: Impacts of IFRS on ROE components

\begin{tabular}{|c|c|c|c|c|c|c|c|c|c|c|}
\hline \multicolumn{3}{|c|}{\begin{tabular}{|c|} 
Distortions of the ROE \\
calculation \\
due to application of the IFRS
\end{tabular}} & $\begin{array}{l}\text { [1] } \\
\text { NR }\end{array}$ & $\begin{array}{c}2] \\
\text { EBIT }\end{array}$ & $\begin{array}{l}\text { [3] } \\
\text { NI }\end{array}$ & $\begin{array}{l}{[4]} \\
\text { SE }\end{array}$ & $\begin{array}{c}{[5]} \\
\text { D }\end{array}$ & $\begin{array}{l}6] \\
\text { NA }\end{array}$ & $\begin{array}{c}\text { [7] } \\
\text { NWC }\end{array}$ & $\begin{array}{c}{[8]} \\
\text { Goodwill }\end{array}$ \\
\hline \multirow{10}{*}{ 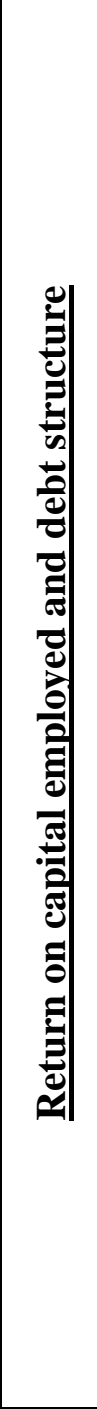 } & \multirow{6}{*}{ 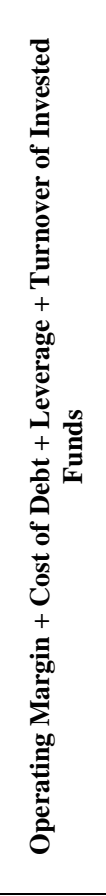 } & $\begin{array}{l}\text { Recording at fair } \\
\text { value }\end{array}$ & & $\mathrm{X}$ & $X$ & $X$ & $\mathrm{X}$ & $\mathrm{X}$ & $X$ & $X$ \\
\hline & & \begin{tabular}{|l} 
Restrictions for \\
internally- \\
generated \\
intangible assets
\end{tabular} & & $X$ & X & $X$ & & $X$ & $X$ & $X$ \\
\hline & & \begin{tabular}{|l|} 
Capitalisation of \\
development \\
costs
\end{tabular} & & $X$ & $X$ & $\mathrm{X}$ & & $X$ & & \\
\hline & & \begin{tabular}{|l|} 
Provisions for \\
depreciation of \\
assets more \\
systematic and \\
generally higher \\
\end{tabular} & & $X$ & $X$ & $X$ & & $X$ & & X \\
\hline & & \begin{tabular}{|l|} 
Mandatory \\
restatement of \\
finance leasing \\
\end{tabular} & & $X$ & X & $X$ & $X$ & $X$ & & \\
\hline & & $\begin{array}{l}\text { Use of the } \\
\text { proportional- } \\
\text { performance } \\
\text { method } \\
\text { Discounting of } \\
\text { proceeds } \\
\text { involving a } \\
\text { delay of } \\
\text { payment }\end{array}$ & $X$ & $\begin{array}{r}X \\
--\end{array}$ & $\begin{array}{c}X \\
- \\
X\end{array}$ & $X$ & & & $X$ & \\
\hline & \multirow{4}{*}{ 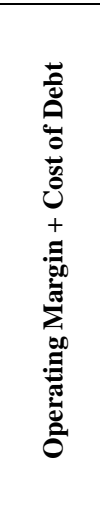 } & $\begin{array}{l}\text { Valuation of } \\
\text { financial } \\
\text { instruments at } \\
\text { fair value }\end{array}$ & & X & X & & & & & \\
\hline & & $\begin{array}{l}\text { Incorporation of } \\
\text { extraordinary } \\
\text { items in the } \\
\text { activity }\end{array}$ & & X & & & & & & \\
\hline & & $\begin{array}{l}\text { Provisions for } \\
\text { pension } \\
\text { commitments }\end{array}$ & & $X$ & X & & & & & \\
\hline & & \begin{tabular}{|l} 
Limited outgoings \\
of financial \\
assets and \\
liabilities
\end{tabular} & & $X$ & X & & & & & \\
\hline 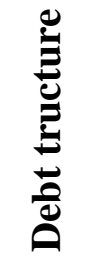 & $\begin{array}{c}\text { Cost of } \\
\text { Debt }\end{array}$ & $\begin{array}{l}\text { Non discounting of } \\
\text { deferred taxes }\end{array}$ & & & X & & & & & \\
\hline
\end{tabular}




\begin{tabular}{|c|c|c|c|c|c|c|c|c|c|c|}
\hline \multicolumn{3}{|c|}{$\begin{array}{l}\text { Distortions of the ROE } \\
\text { calculation } \\
\text { due to application of the IFRS }\end{array}$} & $\begin{array}{l}\text { [1] } \\
\text { NR }\end{array}$ & $\begin{array}{c}{[2]} \\
\text { EBIT }\end{array}$ & $\begin{array}{l}\text { [3] } \\
\text { NI }\end{array}$ & $\begin{array}{c}\text { 4] } \\
\text { SE }\end{array}$ & $\begin{array}{c}\text { [5] } \\
\text { D }\end{array}$ & $\begin{array}{l}\text { [6] } \\
\text { NA }\end{array}$ & $\begin{array}{c}\text { [7] } \\
\text { NWC }\end{array}$ & $\begin{array}{c}{[8]} \\
\text { Goodwill }\end{array}$ \\
\hline \multirow{5}{*}{ 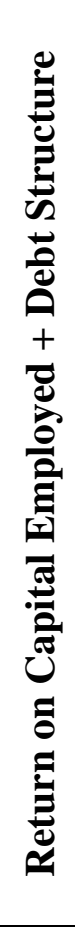 } & 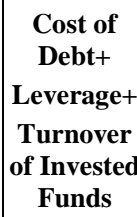 & $\begin{array}{c}\text { Capitalisation of } \\
\text { identifiable } \\
\text { research and } \\
\text { development costs } \\
\text { allowed if asset } \\
\text { conditions are met }\end{array}$ & & $X$ & & & & X & & \\
\hline & \multirow{2}{*}{$\begin{array}{c}\text { Cost of } \\
\text { Debt }+ \\
\text { Leverage }\end{array}$} & \begin{tabular}{|c|} 
Mandatory \\
recording as \\
income of \\
provisions for \\
restructuring of the \\
acquiring firm \\
\end{tabular} & \multicolumn{4}{|c|}{$\mathrm{X}$} & $X$ & & & \\
\hline & & \begin{tabular}{|c|} 
Separate \\
accounting of the \\
components of \\
stockholder equity \\
and debts for quasi \\
stockholder equity
\end{tabular} & \multicolumn{4}{|c|}{$X$} & $\mathrm{X}$ & & & \\
\hline & $\begin{array}{l}\text { Leverage + } \\
\text { Turnover }\end{array}$ & \begin{tabular}{|c|} 
Stricter conditions \\
for outgoings of \\
financial assets \\
and liabilities from \\
the balance sheet
\end{tabular} & \multicolumn{4}{|c|}{$X$} & $X$ & & $X$ & \\
\hline & Funds & $\begin{array}{l}\text { Valuation of } \\
\quad \text { financial } \\
\text { instruments at } \\
\quad \text { fair value }\end{array}$ & \multicolumn{4}{|c|}{$\mathrm{X}$} & $\mathrm{X}$ & & $\mathrm{X}$ & \\
\hline \multirow{2}{*}{ 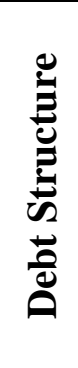 } & \multirow[b]{2}{*}{ Leverage } & \begin{tabular}{|c|} 
More restrictive \\
conditions for \\
making provisions \\
for restructuring of \\
the acquired firm \\
\end{tabular} & \multicolumn{4}{|c|}{$X$} & & & & $\mathrm{X}$ \\
\hline & & \begin{tabular}{|c|} 
Provisions for all \\
pension \\
commitments \\
included according \\
to very precise \\
rules
\end{tabular} & \multicolumn{4}{|c|}{$X$} & & & & \\
\hline
\end{tabular}

Notes: NR (Net revenues), EBIT (Earnings before Interest and Taxes), NI (Net Income), SE (Shareholders' equity), D (Net financial debt), NA (Net noncurrent assets), and NWC (Net working capital $=$ Inventories + Account receivable - Accounts payable) .

It is observed that the formation of ROE becomes axiomatic under the multidimensional and heterogeneous impacts of the IFRS standards on operating margin, cost of debt, leverage and turnover of invested funds. We discuss in Section 4.2 its distortions following the application of the IFRS by analysing the 2004 financial statements of the CAC 40 companies. 


\subsection{Longitudinal analysis of CAC 40 companies}

It is common that before making investment decisions, any investor first needs to perform an analysis of the data and the information related to businesses in order to determine the required rate of return (or expected return on equity). In practice, the latter generally corresponds to the discount rate used in firm valuation models, which incorporates the cost of shareholders' equity. As far as the financial market is not free of information costs (i.e., combination of data collection and analysis costs), the less transparent the firm, the higher the cost of the financial diagnosis, and the more demanding the investor will be concerning the rate of return to cover this information risk. This is exactly the case with the application of the IFRS where investors have little or incomplete information about firm's performance. The impact of information cost on the equilibrium expected return of financial securities can be easily illustrated by Merton (1987)'s model which may be expressed as

$$
\left.E\left(R_{i}\right)-r_{r f}=\beta_{i} \mid E\left(R_{M}\right)-r_{r f}\right\rfloor+\lambda_{i}-\beta_{i} \lambda_{M}
$$

where $E\left(R_{i}\right)=$ refers to the equilibrium expected return on security $i$,

$E\left(R_{M}\right)=$ the equilibrium expected return on the market portfolio,

$r_{r f}=$ the rate of return on a risk-free asset,

$\beta_{i} \quad=$ the beta of security $i$,

$\lambda_{i}=$ the equilibrium aggregate information cost of security $i$ (also called "shadow" cost),

$\lambda_{M}=$ the weighted average shadow cost of incomplete information over all securities available for trading in the stock exchange.

The pricing relationship in Equation (2) shows that Merton (1987)'s model is an extension of the standard Sharpe-Lintner-Mossin CAPM in the context of incomplete information. Note that while the CAPM assumes that specific risk can be totally eliminated by portfolio diversification, in Merton (1987)'s model the greater the specific risk, the higher the equilibrium expected return must be. Accordingly, in case of uncertainties an uninformed investor would not hold the security $i$ without being offered an additional risk premium compensating for information cost. If information is costless (i.e., $\lambda_{M}=\lambda_{M}=0$ ) or the information cost of a particular security is exactly equal to the market shadow cost time its systematic risk sensibility (i.e., $\lambda_{i}=\beta_{i} \lambda_{M}$ ), Merton (1987)'s model 
reduces to the standard CAPM. In sum, the more transparent the firm, the more the Merton's model tends toward the standard CAPM. But, the increased opaqueness of financial and accounting information released under the IFRS will raise the risk premium and thus reduce the convergence between the two models.

Moreover, the financing authorisation order is an important piece of information in assessing profitability and risk. Effectively, if the firm contracts financial debts, it means that the firm has presented sufficient guarantees for potential investors against the risk of default. The firm is, in this case, both more indebted and also sees its market price revaluated by this market confidence index. On the other hand, if the firm increases its equity to finance its growth, the aforementioned reasons are reversed and even add to the suspicions concerning the firm, which allow some investors to attempt to take advantage of a transient overvaluation of the market price. The IFRS rules seem, however, to overweight the shareholder equity, and thus an examination of the accounting documents only can mitigate the initial judgment. To illustrate this purpose, we consider the change in shareholders' equity of ten property companies of the CAC 40 index and find on average an increase of nearly $8 \%$ of their net accounting position. This impact, varying from $6 \%$ to $10 \%$ in general and even reaching more than $26 \%$ in an extreme case, is mainly due to the option for fair valuation of the buildings. There is an increase of about $3 \%$ in shareholders' equity when it is reclassified as quasi shareholders' equity according to IAS 32 and IAS 39 standards, as well as a reduction in the provisions for risks and expenses of about $2 \%$ owing to their possible discounting and losses of amounts recorded under goodwill. If we take into account changes of inverse signs in other companies (e.g., Renault's equity fell by $4 \%$ from $€ 16,444$ million to $€ 15,864$ million, and Casino's equity fell by $8 \%$, with non-current liabilities increasing by $30 \%$ and total liabilities by $16 \%$ ), it would therefore seem that the changes in financial structure induced by the transition to the IFRS is prey to a growing asymmetry of information between the shareholders and the managers, to which in future be added all of the world's States.

Turning out to the overall analysis of CAC 40 firms that have published their financial statements on the internet under both the French GAAP and the IFRS, we first remark that nearly $48 \%$ of these firms experience a variation of more than three basis points in their ROE, as a 
result of moving to the IFRS. ${ }^{4}$ In $80 \%$ of cases we observe an increase in their ROE, and out of the remaining $20 \%$ of firms which recorded a fall in ROE, less than one third involved variations of more than three basis points. In particular, about $14 \%$ of CAC 40 firms experienced a variation in their ROE of more than five basis points. Among these firms, in two thirds of all cases we find a reduction in shareholder equity and operating income, while the net income increases in all cases. Another important point is that we observe a reduction in the revenues from ordinary activities and in the assets, in $80 \%$ of cases.

When looking for the source of the changes in this financial information, we typically see for example that for Axa, the net income goes from $€ 2.5$ to $€ 3.7$ billion, thus a difference of more than $50 \%$. Indeed, this income can be easily obtained by taking back the provisions previously made under the French GAAP for €291 million, by increasing the capital gains on securities whose value has fallen, by eliminating the depreciation of the goodwill which reduced the charges by $€ 607$ million, and by reducing shareholder equity by $4 \%$ with respect to the beginning of 2004. At the same time, the debt to total liabilities ratio goes from $39 \%$ to $42 \%$. In the case of TF1, tangible assets grew by $18 \%$. Accounts receivable go from $€ 912$ million to $€ 1,219$ million or a $34 \%$ increase, and accounts payable go from $€ 892$ million to $€ 1,557$ million or an increase of $43 \%$. With the disappearance of accruals and deferred income the current liabilities go from $€ 2,188$ million to $€ 1,679$ million, meanwhile the noncurrent liabilities passed from $€ 88$ million to $€ 617$ million or a $600 \%$ increase due to reclassification. The operating income dropped, however, by about $4 \%$ from $€ 399$ million to $€ 383$ million.

In order to get more insights about the impact of the IFRS, we also analyse the changes in the ROE by sectors and report the obtained results in Table 2. At the first sight, we observe that the impact of the IFRS is different from one sector to another. The "Aerospace \& defence" and "Audiovisual \& entertainment" sectors had biggest variations in their ROEs ( 8 and 9.42 basis points respectively), while the others, such as the "Banking", "Miscellaneous distributors", and "Basic materials" sectors, saw variations of less than one basis point on average. It should be also noted that most of the sectors experienced average variations in their ROE of about one to five basis points. However, firms in the same sector often

4 The results of analysis for individual firms are not reported here to conserve spaces, but they are entirely available under request to the corresponding author. 
react differently during the transition to IFRS. For example, within the "Automotive \& equipment manufacturers", Michelin had a variation of more than five points, Renault with a variation of between three and five points, and lastly PSA with a variation of less than two points. Similarly, in the "Public-sector services" sector, the ROE of EDF and GDF changes only slightly, whereas substantial variations in the ROE are found for Suez and especially Veolia.

Tab. 2: Average changes in ROE by sector of activity after the transition to the IFRS

\begin{tabular}{|l|c|c|c|c|c|}
\hline & $\begin{array}{c}\text { Net income / } \\
\text { Shareholder } \\
\text { equity } \\
\text { (ROE) }\end{array}$ & $\begin{array}{c}\text { EBIT } / \text { Net } \\
\text { revenues }\end{array}$ & $\begin{array}{c}\text { Net } \\
\text { revenues } \\
\text { / Total } \\
\text { assets }\end{array}$ & $\begin{array}{c}\text { Net } \\
\text { income / } \\
\text { EBIT }\end{array}$ & $\begin{array}{c}\text { Total } \\
\text { liabilities / } \\
\text { Shareholder } \\
\text { equity }\end{array}$ \\
\hline $\begin{array}{l}\text { Audiovisual and } \\
\text { entertainment }\end{array}$ & $9.42 \%$ & $0.60 \%$ & $-4.08 \%$ & $71.59 \%$ & -0.20 \\
\hline $\begin{array}{l}\text { Aerospace and } \\
\text { defence }\end{array}$ & $8.00 \%$ & $0.54 \%$ & $2.61 \%$ & $35.91 \%$ & 0.78 \\
\hline $\begin{array}{l}\text { Specialised } \\
\text { distribution }\end{array}$ & $4.52 \%$ & $-0.22 \%$ & $-11.47 \%$ & $14.24 \%$ & 0.90 \\
\hline $\begin{array}{l}\text { Beverages and food } \\
\text { processing }\end{array}$ & $3.78 \%$ & $0.03 \%$ & $-12.89 \%$ & $7.22 \%$ & 0.70 \\
\hline $\begin{array}{l}\text { Electronics and } \\
\text { electrical equipment }\end{array}$ & $3.69 \%$ & $-0.14 \%$ & $-1.62 \%$ & $31.46 \%$ & 0.08 \\
\hline Technology & $3.68 \%$ & $-1.43 \%$ & $-4.14 \%$ & $82.95 \%$ & -1.58 \\
\hline Oil and gas & $3.64 \%$ & $0.39 \%$ & $-5.19 \%$ & $7.93 \%$ & 0.05 \\
\hline Insurance & $3.49 \%$ & $1.60 \%$ & $-1.24 \%$ & $1.52 \%$ & 0.12 \\
\hline Telecommunications & $3.12 \%$ & $-1.85 \%$ & $-2.19 \%$ & $10.02 \%$ & 0.69 \\
\hline $\begin{array}{l}\text { Media and } \\
\text { advertising }\end{array}$ & $-2.69 \%$ & $-0.83 \%$ & $0.18 \%$ & $36.64 \%$ & -2.85 \\
\hline $\begin{array}{l}\text { Construction and } \\
\text { construction } \\
\text { materials }\end{array}$ & $2.08 \%$ & $0.06 \%$ & $-1.78 \%$ & $10.78 \%$ & 0.07 \\
\hline $\begin{array}{l}\text { Public-sector } \\
\text { services }\end{array}$ & $1.91 \%$ & $1.85 \%$ & $-2.71 \%$ & $-9.02 \%$ & 2.43. \\
\hline $\begin{array}{l}\text { Clothing and } \\
\text { accessories }\end{array}$ & $1.84 \%$ & $-1.17 \%$ & $-12.67 \%$ & $19.82 \%$ & 0.54 \\
\hline
\end{tabular}


Arrouri, M. E. H. - Lévy, A. - Nguyen, D. K.: ROE and Value Creation under

IAS/IFRS: Evidence of Discordance from French Firms.

\begin{tabular}{|l|c|c|c|c|c|}
\hline & \multirow{2}{*}{$\begin{array}{c}\text { Net income / } \\
\text { Shareholder } \\
\text { equity } \\
\text { Sectors }\end{array}$} & $\begin{array}{c}\text { EBIT / } \\
\text { Net } \\
\text { revenues }\end{array}$ & $\begin{array}{c}\text { Net } \\
\text { revenues } \\
\text { / Total } \\
\text { assets }\end{array}$ & $\begin{array}{c}\text { Net } \\
\text { income / } \\
\text { EBIT }\end{array}$ & $\begin{array}{c}\text { Total } \\
\text { liabilities / } \\
\text { Shareholder } \\
\text { equity }\end{array}$ \\
\hline $\begin{array}{l}\text { Automotive and } \\
\text { equipment } \\
\text { manufacturers }\end{array}$ & $1.65 \%$ & $0.16 \%$ & $-3.67 \%$ & $-7.55 \%$ & 0.44 \\
\hline Health and hygiene & $1.28 \%$ & $-1.66 \%$ & $-2.85 \%$ & $24.20 \%$ & 0.01 \\
\hline Travel & $1.08 \%$ & $-0.42 \%$ & $0.34 \%$ & $2.95 \%$ & 0.56 \\
\hline $\begin{array}{l}\text { Personal-care } \\
\text { products }\end{array}$ & $-0.76 \%$ & $13.63 \%$ & $-13.03 \%$ & $-128.0 \%$ & 0.00 \\
\hline Banking & $0.71 \%$ & $0.74 \%$ & $0.00 \%$ & $7.36 \%$ & -1.67 \\
\hline $\begin{array}{l}\text { Miscellaneous } \\
\text { distributors }\end{array}$ & $0.63 \%$ & $0.24 \%$ & $-37.81 \%$ & $40.95 \%$ & 0.25 \\
\hline Basic materials & $0.62 \%$ & $-0.08 \%$ & $-1.56 \%$ & $-0.38 \%$ & 0.21 \\
\hline
\end{tabular}

Notes: this table reports the average sectorial changes in return on equity and its components for CAC 40 companies for the fiscal year of 2004. Average changes are calculated as $\overline{R O E}_{I F R S}-\overline{R O E}_{\text {French GAAP, }}$, where $\overline{R O E}$ stands for the average return on equity.

Next, our results show that the ROE of five different sectors is strongly affected by the application of the IFRS: Audiovisual \& entertainment with Vivendi, Aerospace \& defence with Thalès, Publicsector services with Véolia, Media \& Advertising with Publicis, and Automotive \& equipment manufacturers with Michelin. Table 3 shows that Vivendi had the largest change in its ROE under the IFRS (24.38\%). This increase is explained by the very strong increase in net income under the IFRS, which is not offset by that of shareholders' equity. We equally note the substantial change in the Net Income/EBIT ratio following the move to IFRS $(+142.24 \%)$. It is then clear that the cost of debt accounts for most of the changes in Vivendi's ROE. So the restatements made to reallocate the financial costs are significant. The second-largest change in ROE is found for Thalès, with an increase of $11.55 \%$ according to the application of the IFRS. 


\section{Tab. 3: Changes in ROE for five most impacted sectors after the transition to the IFRS}

\begin{tabular}{|c|c|c|c|c|c|c|}
\hline & & $\begin{array}{c}\text { Net income / } \\
\text { Shareholder } \\
\text { equity (ROE) }\end{array}$ & $\begin{array}{c}\text { EBIT / } \\
\text { Net } \\
\text { revenues }\end{array}$ & \begin{tabular}{|c|} 
Net \\
revenues / \\
Total assets
\end{tabular} & $\begin{array}{c}\text { Net income } \\
\text { / EBIT }\end{array}$ & $\begin{array}{c}\text { Total } \\
\text { liabilities / } \\
\text { Shareholder } \\
\text { equity }\end{array}$ \\
\hline \multicolumn{7}{|c|}{ Audiovisual and entertainment } \\
\hline $\mathrm{V}$ & 2004 FRENCH GAAP & $5.54 \%$ & $10.81 \%$ & $49.50 \%$ & $32.54 \%$ & 3.18 \\
\hline I & 2004 IFRS & $24.38 \%$ & $12.05 \%$ & $41.55 \%$ & $174.78 \%$ & 2.79 \\
\hline $\begin{array}{l}\mathrm{E} \\
\mathrm{N} \\
\mathrm{D} \\
\mathrm{I}\end{array}$ & DELTA & $18.85 \%$ & $1.24 \%$ & $-7.95 \%$ & $+142.24 \%$ & -0.39 \\
\hline \multicolumn{7}{|c|}{ Aerospace and defence } \\
\hline $\mathrm{T}$ & 2004 FRENCH GAAP & $9.46 \%$ & $4.01 \%$ & $62.45 \%$ & $48.08 \%$ & 7.86 \\
\hline $\mathrm{H}$ & 2004 IFRS & $21.01 \%$ & $3.70 \%$ & $76.16 \%$ & $85.52 \%$ & 8.72 \\
\hline $\begin{array}{l}\mathrm{L} \\
\mathrm{E} \\
\mathrm{S}\end{array}$ & DELTA & $11.55 \%$ & $-0.31 \%$ & $13.71 \%$ & $37.45 \%$ & 0.86 \\
\hline \multicolumn{7}{|c|}{ Public-sector services } \\
\hline $\mathrm{V}$ & 2004 FRENCH GAAP & $3.52 \%$ & $3.55 \%$ & $68.04 \%$ & $14.33 \%$ & 10.18 \\
\hline E & 2004 IFRS & $12.15 \%$ & $4.39 \%$ & $64.57 \%$ & $39.66 \%$ & 10.81 \\
\hline $\begin{array}{l}\mathrm{L} \\
\mathrm{I} \\
\mathrm{A}\end{array}$ & DELTA & $8.63 \%$ & $0.84 \%$ & $-3.47 \%$ & $25.33 \%$ & 0.64 \\
\hline \multicolumn{7}{|c|}{ Media and advertising } \\
\hline $\mathrm{P}$ & 2004 FRENCH GAAP & $23.84 \%$ & $7.63 \%$ & $39.35 \%$ & $71.92 \%$ & 11.03 \\
\hline $\begin{array}{l}\mathrm{U} \\
\mathrm{B}\end{array}$ & 2004 IFRS & $16.05 \%$ & $-5.67 \%$ & $38.59 \%$ & $127.91 \%$ & 5.73 \\
\hline $\begin{array}{l}\mathrm{L} \\
\mathrm{I} \\
\mathrm{C} \\
\mathrm{I} \\
\mathrm{S}\end{array}$ & DELTA & $-7.79 \%$ & $-1.96 \%$ & $-0.76 \%$ & $56.00 \%$ & -5.30 \\
\hline \multicolumn{7}{|c|}{ Automotive and equipment manufacturers } \\
\hline \multirow{3}{*}{$\begin{array}{c}\mathrm{M} \\
\mathrm{I} \\
\mathrm{C} \\
\mathrm{H} \\
\mathrm{E} \\
\mathrm{L} \\
\mathrm{I} \\
\mathrm{N}\end{array}$} & 2004 FRENCH GAAP & $11.45 \%$ & $5.52 \%$ & $97.04 \%$ & $60.85 \%$ & 3.51 \\
\hline & 2004 IFRS & $18.44 \%$ & $5.49 \%$ & $93.62 \%$ & $79.18 \%$ & 4.53 \\
\hline & DELTA & $6.99 \%$ & $-0.03 \%$ & $-3.42 \%$ & $18.32 \%$ & 1.02 \\
\hline
\end{tabular}

Notes: this table reports the changes in return on equity and its components for CAC 40 companies by comparing the 2004 ROE ratios established under the French GAAP and IFRS. 
When the ROE is broken down into four components (Table 4), we find that they are not all affected by the IFRS in the same way. On average, the ratios established under the IFRS displayed bigger variations than under the French GAAP, except for the asset turnover (Net revenues/Total assets).

Tab. 4: Analysis of changes in ROE and its components

\begin{tabular}{|l|c|c|c|c|c|}
\hline Accounting standards & $\begin{array}{c}\text { Net income / } \\
\text { Shareholder } \\
\text { equity } \\
\text { (ROE) }\end{array}$ & $\begin{array}{c}\text { EBIT / } \\
\text { Net } \\
\text { revenues }\end{array}$ & $\begin{array}{c}\text { Net } \\
\text { revenues / } \\
\text { Total } \\
\text { assets }\end{array}$ & $\begin{array}{c}\text { Net } \\
\text { income / } \\
\text { EBIT }\end{array}$ & $\begin{array}{c}\text { Total } \\
\text { liabilities / } \\
\text { Shareholder } \\
\text { equity }\end{array}$ \\
\hline $\begin{array}{l}\text { FRENCH GAAP } \\
\text { AVERAGE }\end{array}$ & $14.11 \%$ & $9.14 \%$ & $65.41 \%$ & $83.33 \%$ & 8.44 \\
\hline IFRS AVERAGE & $16.59 \%$ & $9.74 \%$ & $61.26 \%$ & $94.82 \%$ & 8.54 \\
\hline AVERAGE DELTA & $2.48 \%$ & $0.60 \%$ & $-4.15 \%$ & $11.49 \%$ & 0.10 \\
\hline
\end{tabular}

Although the various components that make up the ROE vary from one firm to another when moving to the IFRS, they have certain facts in common. First, the cost of debt expressed by the ratio Net income/EBIT is systematically affected by a significant variation following the adoption of the IFRS. In more than $85 \%$ of cases it is the ratio that varies the most, with an average variation of $+11.49 \%$, compared to its level under the French GAAP. Also, the variation of this ratio is greater than $20 \%$ in more than one third of the cases, and $10 \%$ in two thirds of the cases. It diminishes in $24 \%$ of the cases. Second, the second most strongly affected ratio is the asset turnover. In $80 \%$ of the cases it decreases, and in $5 \%$ of the cases the variation is higher than $20 \%$. Third, the cost-of-debt ratio is systematically raised by more than $2 \%$, and the variation is often greater than 5\%. Forth, while one might expect a strong variation in the leverage ratio (Total liabilities/Shareholder equity) because the IAS/IFRS are said to have a strong effect on shareholder equity, this ratio is only slightly affected. On average it is the ratio showing the smallest variation, compared to the French GAAP ratio (0.10). Finally, the change in the operating-margin ratio occurs in the same manner as that in the leverage ratio.

Summarising all, the move to IAS/IFRS is not without consequences for the ROE of CAC 40 firms since on average the change is 2.5 points. While the effect of the IFRS on shareholder equity is generally 
emphasised in the existing literature, the restatements of net income and operating income appear also to be very significant.

\section{Conclusion}

This study contributes to putting an end to the proposition that the changes in methods and analytical models under the IAS/IFRS are neutral with respect to the assessment of a firm's return on equity. Using consolidated accounting data of CAC 40 firms for the 2004 fiscal year where the application of the IAS/IFRS becomes mandatory, it shows that the increased importance of cash as indicated by the free cash-flows and cash-flow statements could be interpreted as a repudiation of the concept of profit. In fact, both the old indicators developed under the French GAAP ("Excédent Brut d'Exploitation", "Résultat d'explotation", "Résultat courant", etc.) and the redefined ones (EBITDA, EBIT, Profit before tax and non recurrent items, etc.) are now based on a concept of earnings linked to calculated revenues and expenses, which is thus subject to an opportunistic management of earnings. Meanwhile, we can understand this tendency to return to cash flow because it is not influenced by the entities' accounting policies, and has an undeniable advantage as a measure of risk.

\section{References}

[1] Atiase, R. K. - Bamber, L. S. (1994): Trading Volume Reaction to Annual Accounting Earnings Announcements. Journal of Accounting and Economics, 1994, vol. 17, no. 3, pp. 113-128.

[2] Beaver, W. H. (1968): The Information Content of Annual Earnings Announcements. Journal of Accounting Research, 1968, vol. 6 (Supplement), pp. 67-92.

[3] Bertoni, M. - De Rosa, B. (2006): Measuring Balance Sheet Conservatism: Empirical Evidence from Italian First Time Adopters of IFRS. In: Proceedings of the international conference Emerging Issues in International Accounting and Business, Padova, University of Padova, 2006, pp. 33-54. 
[4] Bischof, J. (2009): The Effects of IFRS 7 Adoption on Bank Disclosure in Europe. Accounting in Europe, 2009, vol. 6, no. 2, pp. 167-194.

[5] Botosan, C. (1997): Disclosure Level and the Cost of Equity Capital. Accounting Review, 1997, vol. 72, no. 2, pp. 323-349.

[6] Botosan, C. - Plumlee, M. (2002): A Re-examination of Disclosure Level and the Expected Cost of Equity Capital. Journal of Accounting Research, 2002, vol. 40, no. 1, pp. 21-40.

[7] Bouton, D. (2002): Pour un meilleur gouvernement des entreprises cotées. Paris, Association Françaisedes Entreprises Privées Mouvement des Entreprises de France, 2002.

[8] Bozzolan, S. - Trombetta, M. - Beretta, S. (2009): Forward-looking disclosures, financial verifiability and analysts' forecasts: A study of cross-listed European firms. European Accounting Review, 2009, vol. 18 , no. 3, pp. 435-473.

[9] Brown, L. D. - Han, J. C. Y. (1992): The Impact of Annual Earnings Announcements on Convergence of Beliefs. Accounting Review, 1992, vol. 67, no. 4, pp. 862-875.

[10] Bushman, R. - Smith, A. (2001): Financial Accounting Information and Corporate Governance. Journal of Accounting and Economics, 2001, vol. 32, no. 1-3, pp. 237-334.

[11] Callao, S. - Jarne, J. - Lainez, J. (2007): Adoption of IFRS in Spain: Effect on the Comparability and Relevance of Financial Reporting. Journal of International Accounting, Auditing and Taxation, 2007, vol. 16, no. 2, pp. 148-178.

[12] Cuijpers, R. - Buijink, W. (2005): Voluntary Adoption of Non-local GAAP in the European Union: A Study of Determinants and Consequences. European Accounting Review, 2005, vol. 14, no. 3, pp. 487-524.

[13] Diamond, D. - Verrecchia, E. (1991): Disclosure, Liquidity, and the Cost of Capital. Journal of Finance, vol. 46, no. 4, pp. 1325-1359. 
[14] Ding, Y. - Hope, O. K. - Jeanjean, T. - Stolowy, H. (2007): Differences between Domestic Accounting Standards and IAS: Measurement, Determinants and Implications, Journal of Accounting and Public Policy, 2007, vol. 26, no. 1, pp. 1-38.

[15] Dumontier, P. - Maghraoui, R. (2006): Adoption volontaire des IFRS, asymétrie d'information et fourchettes de prix: l'impact du contexte informationnel. Comptabilité Contrôle Audit, 2006, vol. 12, no. 2, pp. 27-48.

[16] Frankel, R. - McNichols, M. - Wilson, G.P. (1995): Discretionary Disclosure and External Financing. Accounting Review, 1995, vol. 70, no. 1, pp. 135-150.

[17] Grossman, S. (1981): The Informational Role of Warranties and Private Disclosure about Product Quality, Journal of Law and Economics, vol. 24, no. 3, pp. 461-483.

[18] Jensen, M. - Meckling, W. (1976): Theory of the Firm: Managerial behaviour, Agency Costs and Ownership Structure. Journal of Financial Economics, 1976, vol. 3, no. 4, pp. 305-360.

[19] Jiraporn, P. - Miller, G. A. - Yoon, S. S. - Kim, Y. S. (2008): Is Earnings Management Opportunistic or Beneficial? An Agency Theory Perspective. International Review of Financial Analysis, 2008, vol. 17 , no. 3, pp. 622-634.

[20] Joos, P. - Lang, M. (1994): The Effects of Accounting Diversity: Evidence from the European Union. Journal of Accounting Research, 1994, vol. 32(Supplement), pp. 141-168.

[21] Kim, O. - Verrecchia R. (1994): Market Liquidity and Volume around Earnings Announcements. Journal of Accounting and Economics, vol. 17, no. 1-2, pp. 41-67.

[22] Lang, M. - Lundholm, R. (1996): Corporate Disclosure Policy and Analyst Behaviour. Accounting Review, 1996, vol. 71, no. 4, pp. 467-492.

[23] Lantto, A. M. - Sahlström, P. (2009): Impact of International Financial Reporting Standard Adoption on Key Financial Ratios. Accounting and Finance, 2009, vol. 49, no. 2, pp. 341-361. 
[24] Laux, C. - Leuz, C. (2010): Did Fair-value Accounting Contribute to the Financial Crisis? Journal of Economic Perspectives, 2010, vol. 24, no. 1, pp. 93-118.

[25] Leuz, C. (2003): IAS versus U.S. GAAP: Information Asymmetrybased Evidence from Germany's New Market. Journal of Accounting Research, 2003, vol. 41, no. 3, pp. 445-472.

[26] Lev, B. - Zarowin, P. (1999): The Boundaries of Financial Reporting and how to Extend them. Journal of Accounting Research, 1999, vol. 37, no. 2, pp. 353-385.

[27] Merton, R. (1987): A Simple Model of Capital Market Equilibrium with Incomplete Information. Journal of Finance, vol. 42, no. 3, pp. 483-510.

[28] Milgrom, P. R. (1981): Good News Bad News: Representation Theorems and Applications. Bell Journal of Economics, 1981, vol. 12 , no. 2, pp. 380-391.

[29] Modigliani, F. - Miller, M. H. (1958): The Cost of capital, Corporate Finance and the Theory of Investment. American Economic Review, 1958, vol. 48, no. 3, pp. 261-297.

[30] Ohlson, J. (1995): Earnings, Book Values and Dividends in Equity Valuation. Contemporary Accounting Research, 1995, vol. 11, no. 2, pp. 661-687.

[31] Park, M. S. - Rio, B. T. (2004): The Effect of Firm-industry Correlation and Announcement Timing on Firms' Accrual Decisions. British Accounting Review, vol. 36, no. 3, pp. 269-289.

[32] Peterson, D. - Peterson, P. (1995): Abnormal Returns and Analysts' Earnings Forecast Revisions Associated with the Publication of Stock Highlights by Value Line Investment Survey. Journal of Financial Research, 1995, vol. 37, no. 2, pp. 353-385.

[33] Ramond, O. - Batsch, L. - Casta, J. F. (2007) : Résultat et performance financière en normes IFRS: quel est le contenu informatif du comprehensive income? Comptabilité Contrôle Audit, vol. 13, pp. 129-154. 
[34] Richardson, S. A., Tuna, A. I. - Wu, M. (2002): Predicting Earnings Management: the Case of Earnings Restatements. Working Paper, Wharton School, University of Pennsylvania, 2002.

[35] Schipper, K. (2005): The Introduction of International Accounting Standards in Europe: Implications for the International Convergence. European Accounting Review, 2005, vol. 14, no. 1, pp. 101-126.

[36] Sengupta, P. (1998): Corporate Disclosure Quality and the Cost of Debt. Accounting Review, 1998, vol. 73, no. 4, pp. 459-474.

[37] Street, D. L. Nichols, N. B. - Gray, S. J. (2000): Assessing the Acceptability of International Accounting Standards in the US: an Empirical Study of the Materiality of US GAAP Reconciliations by Non-US Companies Complying with IASC Standards. International Journal of Accounting, 2000, vol. 35, no. 1, pp. 27-63.

[38] Tort, E. (2005): Étude d'impact de la conversion des foncières cotées aux normes comptables internationales. Revue Française de Comptabilité, 2005, no. 380, pp. 50-54.

[39] Whittington, G. (2005): The Adoption of International Accounting Standards in the European Union. European Accounting Review, 2005, vol. 14, no. 1, pp. 127-153. 


\title{
ROE and Value Creation under IAS/IFRS: Evidence of Discordance from French Firms
}

Mohamed El Hedi AROURI - Aldo LEVY - Duc Khuong NGUYEN

\begin{abstract}
This paper re-examines the effects that adoption of the International Financial Reporting Standards (IFRS) has had on financial reporting of French listed firms. By analysing the 2004 financial statements of CAC 40 companies, we show that the transition to the IAS/IFRS has a significant impact on the return on equity (ROE) of considered firms by increasing it by 25 basis points on average, compared to the French GAAP. This finding thus suggests an amplified degree of discordance between the ROE, as a crucial measure of firm performance, and the value creation process following the IFRS adoption. From a theoretical viewpoint, Merton (1987)'s capital asset pricing model (CAPM) with incomplete information, which claims its convergence to its traditional version through the reduction of information costs, cannot in fact be valid, owing to divergences in the assessment of a firm's performance.
\end{abstract}

Key words: IAS/IFRS; Return on equity; Financial leverage.

JEL classification: M41; L25. 